\title{
What does the structure-function relationship of the HIV-I Tat protein teach us about developing an AIDS vaccine? Grant R Campbell ${ }^{1}$ and Erwann P Loret*2
}

\author{
Address: ${ }^{1}$ Department of Pediatrics, Division of Infectious Diseases, University of California San Diego, 9500 Gilman Drive, La Jolla, California \\ 92093-0672, USA and 2Unité Mixte de Recherche Université de la Méditérranée/Institut National de la Santé et de la Recherche Médicale U911, \\ Faculté de Pharmacie, 27 Bd Jean Moulin, 13385 Marseille, France \\ Email: Grant R Campbell - gcampbell@ucsd.edu; Erwann P Loret* - erwann.loret@pharmacie.univ-mrs.fr \\ * Corresponding author
}

Published: 25 May 2009

Retrovirology 2009, 6:50 doi:10.1186/1742-4690-6-50

This article is available from: http://www.retrovirology.com/content/6/I/50

C 2009 Campbell and Loret; licensee BioMed Central Ltd.

This is an Open Access article distributed under the terms of the Creative Commons Attribution License (http://creativecommons.org/licenses/by/2.0), which permits unrestricted use, distribution, and reproduction in any medium, provided the original work is properly cited.
Received: 22 January 2009

Accepted: 25 May 2009

\begin{abstract}
The human immunodeficiency virus type I (HIV-I) trans-activator of transcription protein Tat is an important factor in viral pathogenesis. In addition to its function as the key trans-activator of viral transcription, Tat is also secreted by the infected cell and taken up by neighboring cells where it has an effect both on infected and uninfected cells. In this review we will focus on the relationship between the structure of the Tat protein and its function as a secreted factor. To this end we will summarize some of the exogenous functions of Tat that have been implicated in HIV-I pathogenesis and the impact of structural variations and viral subtype variants of Tat on those functions. Finally, since in some patients the presence of Tat-specific antibodies or CTL frequencies are associated with slow or non-progression to AIDS, we will also discuss the role of Tat as a potential vaccine candidate, the advances made in this field, and the importance of using a Tat protein capable of eliciting a protective or therapeutic immune response to viral challenge.
\end{abstract}

\section{Review}

\section{Introduction}

Human immunodeficiency virus type 1 (HIV-1) exhibits high genetic variability, with strains divided into three main groups: major $(\mathrm{M})$, which are the cause of most HIV1 infections worldwide, outlier $(\mathrm{O})$ and new $(\mathrm{N})$ that are non $\mathrm{M}$ and non $\mathrm{O}$ [1]. Within group $\mathrm{M}$, nine subtypes are recognized, designated by the letters A-D, F-H, J and K. In addition, circulating recombinant forms (CRF) have also been identified [1]. Globally, over 50\% of all infections are caused by subtype $C$ which is found mainly in subSaharan Africa, India and South America, whereas subtype $\mathrm{B}$, the most studied clade, represents $10 \%$ of all infections, and is dominant in both Europe and America. Subtypes A and $\mathrm{D}$ are found in sub-Saharan Africa and account for $12 \%$ and $3 \%$ of infections respectively, while CRF_01_AE is found mainly in south east Asia and represents 5\% of all infections worldwide [1]. Recent research has shown that the different subtypes and CRF of HIV-1 have biological differences with respect to transmission [2], replication [3] and disease progression [4,5]. Moreover, the HIV-1 proteins gp120 [6], Nef [7], Vif, Vpr, Vpu [8,9] and Tat [10-19] show clade and isotype-specific properties at both the molecular and biological levels. Therefore, a generalization of our understanding of HIV-1 subtype B transmission, pathogenesis and tissue involvement across all subtypes is questionable.

The HIV-1 trans-activator of transcription (Tat) is an 86101 residue regulatory protein $(9-11 \mathrm{kDa})$ that is essential for the productive and processive transcription from the HIV-1 long terminal repeat (LTR) promoter [20-22]. 
Tat binds to a short nascent stem-bulge loop leader RNA, termed the trans-activation responsive region, or TAR $[23,24]$, that is present at the 5 ' extremity of all viral transcripts via its basic region and recruits the complex of cyclin $\mathrm{T} 1$ and cyclin-dependent kinase 9 (CDK9) forming the positive transcription elongation factor B complex. CDK9 hyperphosphorylates the carboxy terminus domain of RNA polymerase II, leading to the enhanced elongation of transcription from the viral promoter. For Tat's transcriptional activity, it has recently been reported that Tat is regulated by lysine methylation [25], and that it interacts with a histone chaperone nucleosome assembly protein [26].

In addition to its primary role as a transcriptional activator of viral gene expression, Tat is actively released from unruptured, HIV-1-infected cells and is detectable in ex vivo culture supernatants and in the serum of HIV-1 infected individuals at concentrations up to $40 \mathrm{ng} / \mathrm{mL}$ $[27,28]$. This exogenous Tat is able to enter both uninfected and latently infected cells, inducing apoptosis in the former and activating the transcription of the viral genome in the latter. The precise mechanism by which Tat enters cells is under investigation and will not be discussed here. However, no specific receptor has been implicated in the uptake of Tat and conflicting results have been obtained for the involvement of macropinocytosis [29], clathrin-mediated endocytosis [30] and caveolae/ lipid-raft-mediated endocytosis [31]. Thus, Tat fulfills a role in HIV-1 pathogenesis not only as an essential protein for HIV-1 replication, but also as an extra-cellular toxin [32]. Therefore, it is relevant to develop a vaccine targeting Tat [33]. However, antibodies against Tat are found in almost $50 \%$ of seropositive patients but are unable to recognize Tat variants from all HIV-1 subtypes [17]. Moreover, these antibodies fail to slow disease progression to AIDS [34].

Understanding the structure-function relationship in respect to the exogenous roles of Tat may have important clinical implications, both for the development of new vaccines against AIDS targeting Tat. Here, we present the latest advances in elucidating the structure of Tat. We will also summarize some of the roles exogenous Tat has been shown to fulfill, and the impact that structural variations of Tat may have on these functions. Finally, we will also discuss the role of Tat as a potential vaccine candidate.

\section{Structures of Tat variants}

HIV-1 Tat is a small nuclear protein that exists predominantly in two different lengths - 86-87 residues or 99101 residues - and is encoded by two exons [20]. The long 99-101 residue forms are predominant in clinical isolates from all HIV-1 subtypes excepted subtype D, which has a non-synonymous single nucleotide polymorphism, creat- ing a stop codon in the second exon encoding sequence. However, some subtype $\mathrm{B}$ isolates have been found that have this truncated form, and is the form of Tat most used in research $[15,20]$. Tat is divided into six regions [35] with the one termed the basic region being involved in most of Tat's functions [20]. Nuclear magnetic resonance spectroscopy (NMR) studies of biologically active Tat variants revealed that the basic region and the other functional regions are well exposed to solvent and surround a core composed of part of the N-terminus, where the well conserved $\operatorname{Trp}^{11}$ is found [36-38]. This folding is similar between different Tat variants in aqueous solution but can change dramatically when exposed to hydrophobic solvents [10]. Tat is a flexible protein, and structural changes are probably necessary for it to bind to its pharmacological targets [39].

\section{Primary structure}

Tat was first described as a trans-activator of HIV-1 genes [40]. Although trans-activation can be observed in vitro with the first exon (residues 1-72), the second exon that codes for 14 to 34 amino acids at the C-terminal extremity is necessary to observe trans-activation in vivo [20]. Figure 1 shows a selection of Tat sequences obtained using solid phase synthesis [10] that all have trans-activational transcription activity (excepted Tat Oyi). This data show that Tat can tolerate up to $40 \%$ sequence variation without loss of activity [41].

Tat is divided into six different functional regions [35]. Region I (residues $1-21$ ) is a proline-rich region and has a conserved Trp ${ }^{11}$. Region II (residues 22-37) has seven well conserved cysteines at positions 22, 25, 27, 30, 31, 34 and 37 except for subtype $\mathrm{C}$ which has a C31S mutation. These cysteines appear to be free and no other cysteines are found in the sequence except in CRF_01_AE (Figure 1) and CRF_01_AG [42]. It was proposed that a functional Tat could have cysteines bound to zinc [40]. The functional test was the in vitro modulation of microtubule assembly but a same effect is obtained with a Tat peptide (residues 38-72) that does not contain the cysteine rich region [18]. The trans activation assay in vivo with different synthetic Tat variants does not require zinc binding [10]. Region III (residues 38-48) has a conserved Phe ${ }^{38}$ and the conserved sequence ${ }^{43}$ LGISYG. Region IV (residues 49$59)$ is rich in basic residues and has the rather well conserved sequence ${ }^{4}{ }^{9}$ RKKRRQRRRPP. Region V (residues $60-72$ ) is the glutamine-rich region and has the highest rate of sequence variation. Region VI constitutes the C-terminus of Tat, is encoded by the second exon, and contains a conserved RGD motif in subtypes B and D [20].

\section{Secondary Structure}

Circular dichroism reveals that the main secondary structure in aqueous solution is the $\beta$-turn with an average of 


\begin{tabular}{|c|c|}
\hline HXB2 & $\begin{array}{l}1 \ldots \ldots 10 \ldots \ldots 20 \ldots \ldots \\
\text { MEPVDPRLEPWKHPGSQPKTACTNCYCKKCCFHCQVCFITKALGISYGRKKRRQRRRAHQNSQTHQASLSKO }\end{array}$ \\
\hline Bru & 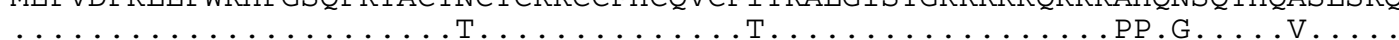 \\
\hline Jr & TK.G......... \\
\hline Oyi & 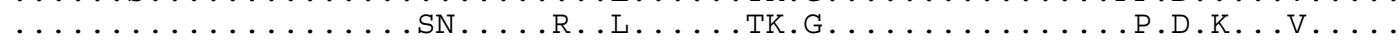 \\
\hline $93 \mathrm{In}$ & $\ldots$. .SY . L . .QK.GL . . . . . . . . S.P.S.ED..NPI. \\
\hline $96 \mathrm{Bw}$ & 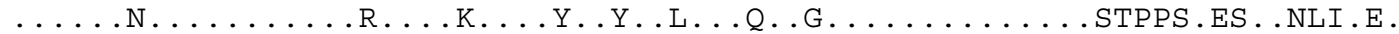 \\
\hline $92 \mathrm{Br}$ & 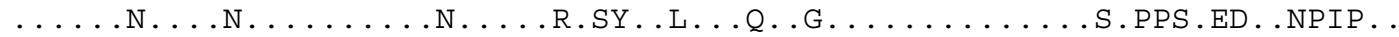 \\
\hline Eli & 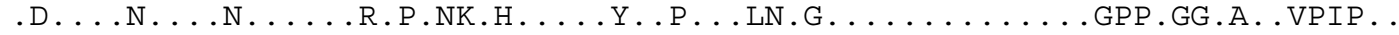 \\
\hline Mal & 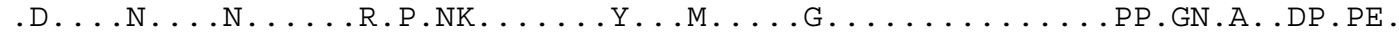 \\
\hline $\mathrm{Z} 2$ & 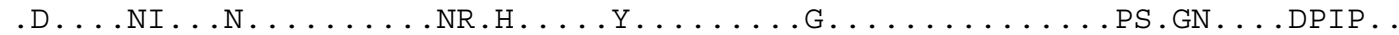 \\
\hline Ug05RP & $\ldots$. . SI ..N. . . . R.P.NK. . . . Y...L. \\
\hline Ug11LTS & $\ldots$....I. ...G............SP.GDH...DPIP. \\
\hline Ug11RP & 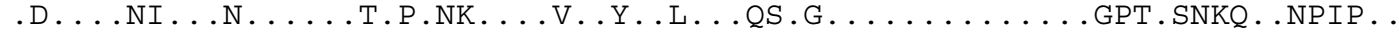 \\
\hline CM2 40 & 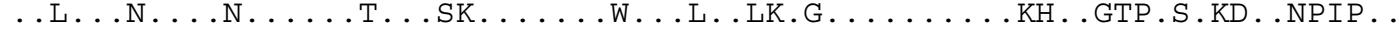 \\
\hline
\end{tabular}

Exon II

HXB2

Bru

Jr

Oyi

93 In

$96 \mathrm{BW}$

92Br

Eli

Mal

$\mathrm{Z} 2$

Ug05RP

Ug11LTS

Ug11RP

CM2 40

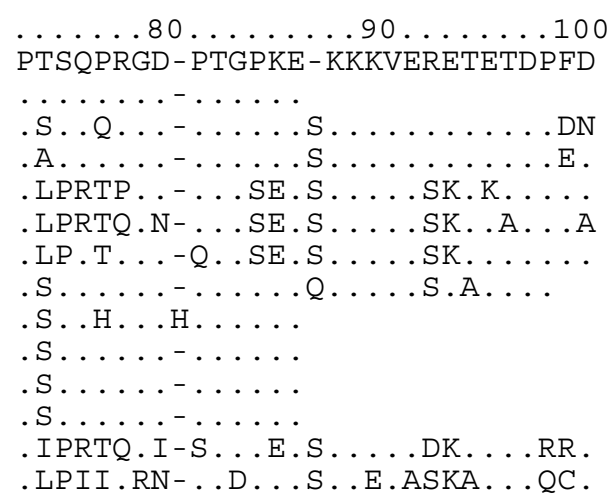

Country
France
France
USA
Gabon
India
South Africa
Brazil
DR Congo
DR Congo
DR Congo
Uganda
Uganda
Uganda
Thailand

Clade
B
B
B
B
C
C
C
D
D
D
D
D
A
CRF AE

\section{Figure I}

Tat sequences representative of the five main HIV-I subtypes. The sequence length of Tat is variable and ranges from 86 to $10 \mathrm{I}$ residues as a function of the second exon. A viable strain having only the first exon of Tat (72 residues) has never been observed in vivo. Subtype variability follows the geographical diversity of HIV-I with subtype B Tat sequences being the most divergent compared to subtypes $A, C, D$ and CRF_AE. These Tat variants have been synthesized using solid phase synthesis and have been shown to be able to cross membranes and trans-activate the HIV-I LTR except for Tat Oyi [I0, I4$16,4 \mid, 52]$.

$30 \%$ among Tat variants and almost no $\alpha$-helix [10]. However, the secondary structures of Tat are dependent upon its environment and change dramatically with an $\alpha$ helix becoming the main secondary structure in hydrophobic solvents [10]. These changes reveal that Tat is highly flexible, and this is almost certainly related to the capacity of Tat to cross cell membranes.

Peptides corresponding to the different Tat regions show the same capacity of change in the secondary structures with respect to its environment as the native protein [43]. However, regions I and VI are less flexible, probably due to their high proline content (Figure 1). Interestingly, region III seems to be the only one able to adopt a $\beta$-turn structure independently from the other regions [43]. Chemical modification of the seven cysteines dramatically changes the CD spectrum of Tat Bru (Figure 2) revealing significant structural changes [10].

\section{Tertiary structure}

No X-ray crystallography structural studies of a full length Tat have been performed, but four NMR studies of Tat variants with two exons have been reported (Figure 3). The first NMR structural study was performed under reducing conditions using an 86-residue Tat $\mathrm{Z2}$ variant in the presence of dithiothreitol (DTT) [44]. The oxidation state of the cysteine residues is important when considering Tat's trans-activational function as Tat becomes inactive when incubated with strong reducing agents such as DTT or 2mercaptoethanol [45]. Furthermore, chemical modification of cysteines changes dramatically the CD spectrum of Tat [10]. Only 25 long distance NMR constraints, mainly located in regions III and V were obtained in this study [44]. Two later studies of the 86-residue Tat Bru [36] and the 87-residue Tat Mal [37] were performed in the absence of reducing agents and over 270 long-range NMR constraints were found in each. Both Tat proteins displayed 


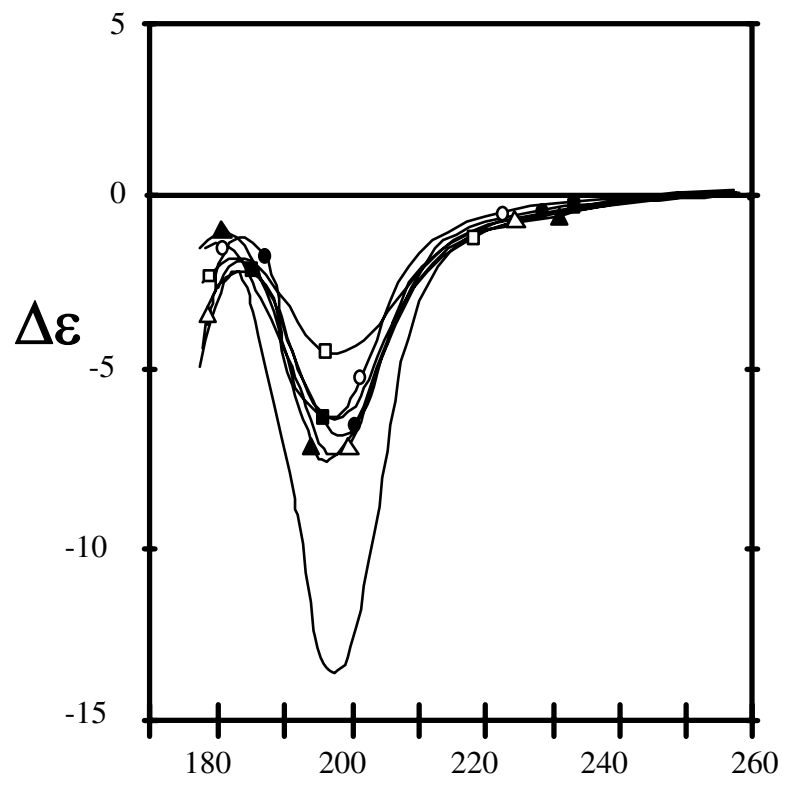

Wavelength $(\mathrm{nm})$

\section{Figure 2}

Circular dichroism (CD) spectra of Tat variants in aqueous solution. Tat Z2 (white triangle), Tat Oyi (black triangle), Tat Bru (white circle), Tat Bru cmC (no mark), Tat Jr (black circle), Tat Mal (white square) and Tat Eli (black square) were measured from 260 to $178 \mathrm{~nm}$ with a $50 \mu \mathrm{M}$ path length in $20 \mathrm{mM}$ phosphate buffer, $\mathrm{pH} 4.5$. It is not possible to gather $C D$ spectra into two categories composed of short Tat (white mark) or long Tat (black mark). The intense magnitude of the $200 \mathrm{~nm}$ band observed with Tat Bru cmC shows that chemical modifications of cysteines modify the folding of Tat.

different folding to that of Bayer et al. [44] but similar to each other. Tat Mal has a sequence similar to Tat Z2 (Figure 1), and the CD spectrum of Tat $\mathrm{Z} 2$ in the absence of reducing agents is similar to that of both Tat Mal and Tat Bru; both of which have been shown to be biologically active in the absence of reducing agents. Therefore, it is probable that the different folding observed in the NMR study of Tat $\mathrm{Z} 2$ (Figure $3 \mathrm{~A}$ ) is due to a structural change induced by the reducing conditions. An NMR study of a reduced peptide corresponding to the first exon of Tat (residues 1-72) combined with a $\mathrm{His}_{6}$ segment and T7 epitope that added 20 residues to the N-terminus resulting in a 92-residue peptide has also been performed recently [46]. In this case, the authors were unable to identify NMR constraints and stated that Tat was a naturally unfolded protein. It is surprising to deduce this statement for all Tat variants from the study of a 72 residue reduced Tat-His $_{6}$ T7 peptide as no viable HIV-1 strain consisting of

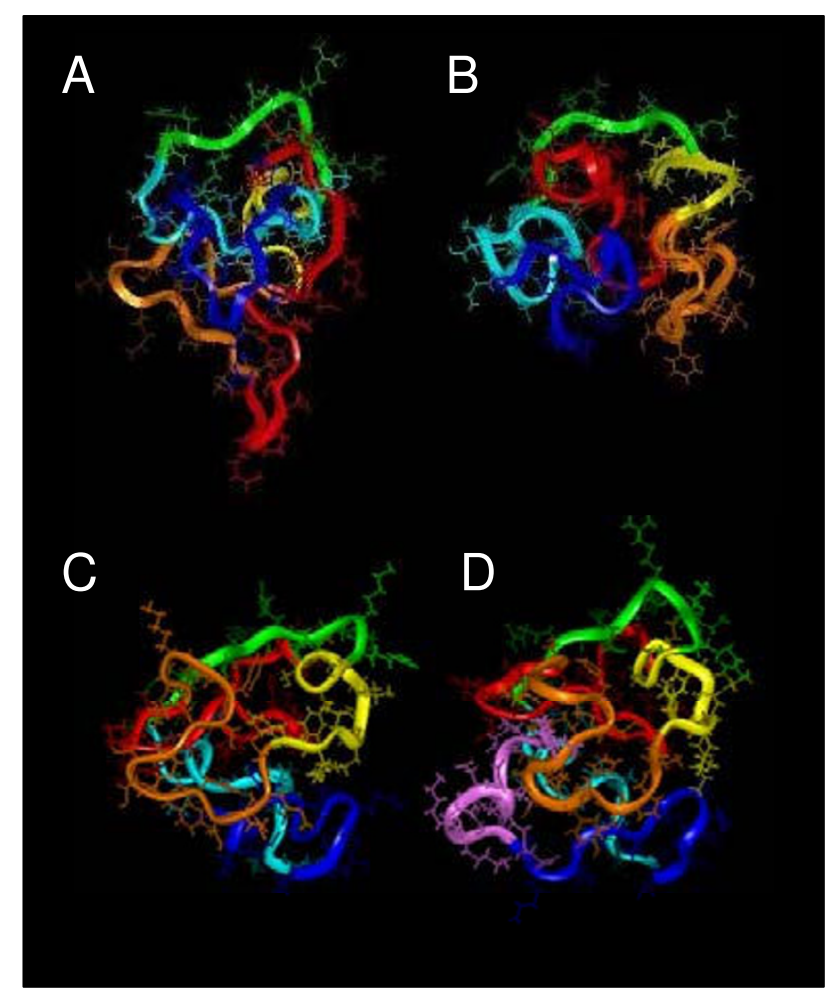

Figure 3

NMR studies of Tat proteins. Tat Z2 (A), Tat Bru (B), Tat Mal (C), and Tat Eli (D) 3D structures obtained from NMR constraints [36-38,44]. Region I is depicted in red, region II (cysteine-rich region) in orange, region III in yellow, region IV (basic region) in green, region $\mathrm{V}$ in light blue, region $\mathrm{VI}$ (residues 73-86/87) in blue and for Tat Eli the extra C-terminal residues are in pink. The Tat $Z 2$ variant used had chemically modified cysteines which affected biological activity and 3D structure. The three Tat variants with biological activity $(B, C$ and $\mathrm{D}$ ) displayed a similar folding characterized by a core region composed of part of region I with the highly conserved TrP "I while the functional region II, IV and V are well exposed to the solvent. The extra residues in the $\mathrm{C}$-terminus of Tat Eli are exposed to the solvent and protrude from a groove between the basic region and the cysteine-rich region.

only the first exon of Tat has ever been observed in vivo. Furthermore, the sequence used for this study does not correspond to a viable HIV-1 strain, as the peptide contained a supplemental 20 residues at the $\mathrm{N}$-terminus that are unrelated to Tat. The trans-activational activity of this peptide was not tested or its ability to induce TNF production from monocytes; so it is not possible to determine if this study was biologically relevant. Moreover, a conserved Tat folding is also confirmed by numerous vaccine studies that raised antibodies against Tat conformational epitopes in HIV-1-infected individuals and SHIV-1infected macaques $[17,47-50]$. Taken together, these find- 
ings indicate that Tat with its two exons should exist in a stable conformation in vivo. Furthermore, the second exon of Tat was is essential to get a biologically functional Tat in a number of different assays [41,51-53]. Therefore, the collective studies indicate that the second exon of Tat is important to the stability of the structure. The last NMR study of Tat to be reported was the first report of a NMR structure for a full-length Tat and was performed using the 99-residue Tat Eli variant [38]. Figure 3D shows that Tat Eli has a core region made up of a part of the N-terminus with the highly conserved $\operatorname{Trp}^{11}$ and a folding similar to Tat Bru and Tat Mal with the extra residues at the Tat Eli C-terminus protruding from a groove between the basic region and the cysteine-rich region that is well exposed to solvent [38].

The main secondary structure building block in Tat variants is the $\beta$-turn [36-38]. The core of Tat is composed primarily of aromatic residues organized in a hydrophobic cluster involving the highly conserved Trp ${ }^{11}$ and $P h e^{38}$, with a part of region I adopting an extended structure that crosses the protein and constitutes the core region, with the other regions well exposed to the solvent packing around the core. This core region might be involved in the process that occur during Tat internalization and certainly requires a structural change for this hydrophobic environment. The basic region (region IV) adopts an extended structure while regions II, III, V and VI have $\beta$-turns except for Tat Mal, which has an $\alpha$-helix in region $\mathrm{V}$. It is interesting to note that the NMR spectra of Tat variants show a low chemical shift dispersion indicative of a rather flexible structure, which might be a prerequisite for its ability to cross membranes.

In conclusion, structural studies carried out on Tat variants with biological activity show that Tat variants have a similar folding in aqueous solution characterized by a core region composed of a part of region I, which is surrounded by the other regions that are well exposed to solvent. Mutations observed between Tat variants from different HIV-1 subtypes induce local structural variations such as the presence in region $\mathrm{V}$ of an $\alpha$-helix in Tat Mal instead of two $\beta$-turns in Tat Bru and Tat Eli. Tat is rather flexible, and its folding can dramatically change between aqueous and hydrophobic environments.

\section{Extra-cellular functions of Tat}

In addition to the major role of transcriptional activation of viral gene expression, Tat has been implicated in a number of extra-cellular functions during HIV-1 infection. Several studies have suggested that Tat plays a role in viral infectivity and contributes to HIV-1 pathogenesis [20]. For example, immature dendritic cells exposed to exogenous Tat mature and upregulate key co-stimulatory molecules such as CD40, CD80, CD86, lymphocyte func- tion-associated antigens, major histocompatibility complex (MHC) class I and II, lymphotoxin, chemokine (C-C motif) ligand (CCL) 3, CCL4, CCL5, interleukin (IL)-12 and tumor necrosis factor (TNF) [51].

Interaction of Tat with integrins and its role in Kaposi's Sarcoma The first extra-cellular role postulated for Tat was in its direct contribution to Kaposi's sarcoma (KS) associated with AIDS [27,53]. KS is an unusual neoplasm that is typically an indolent disease caused by the human herpesvirus- 8 (HHV-8), affecting the skin of elderly males, and is not life threatening. However, AIDS-related KS (AIDS-KS) is dramatically more frequent and more aggressive [54]. Early experiments with transgenic mice with the tat gene showed that they rapidly developed dermal lesions resembling KS [55]. Consistent with this finding, exogenous subtype B Tat was shown to stimulate the growth of cells of mesenchymal origin derived from Kaposi's sarcoma lesions of AIDS patients, and was inhibited by anti-Tat antibodies [27]. B Tat also induces the growth and locomotion of primary endothelial cells activated with inflammatory cytokines, in particular, interferon (IFN)- $\gamma$, TNF and IL- $1 \beta$, which are increased in the blood and lesions of AIDS-KS individuals. IFN- $\gamma$, TNF and IL- $1 \beta$ also augment the synthesis and release of basic fibroblast growth factor (bFGF) from the spindle cells of KS lesions and induce its production from endothelial cells [56,57]. In vivo, bFGF exists primarily bound to heparan sulfate proteoglycans, protected from proteolytic degradation, at the surface of cells and extra-cellular matrix, with only a fraction being found in soluble form. Tat, through its conserved basic region, competes with bFGF for heparin-binding sites, increasing soluble bFGF to concentrations that promote spindle cell and endothelial cell growth [56,57] and upregulates the integrins $\alpha_{5} \beta_{1}$ and $\alpha_{\mathrm{v}} \beta_{3}$, receptors for fibronectin and vitronectin, respectively, both of which are highly expressed in AIDS-KS [58]. One of the similarities between fibronectin, vitronectin and subtypes B and $\mathrm{D}$ Tat is the presence in the C-terminal domain of Tat of an RGD motif, which represents the principal cell attachment moiety recognized by integrin receptors. Engagement of integrins during endothelial cell adhesion regulates their migration, tissue organization, matrix remodeling, and, with receptors for soluble factors, survival, differentiation, and proliferation. Therefore, Tat, by engaging with integrin receptors via its RGD motif, promotes the locomotion of spindle cells and activated endothelial cells and provides the adhesion signal they require in order to grow in response to bFGF [59]. This motif has also been implicated in inducing the migration of monocytes and neutrophils through integrins $\alpha_{5} \beta_{1}$ and $\alpha_{\mathrm{v}} \beta_{3}$ [60]. Mutations in this RGD motif or antibodies derived against this motif prevent the attachment of Tat to integrins [59]. Interestingly, not all Tat subtypes posses 
this motif, indicating possible subtype specific responses to HHV-8 in HIV-1-infected individuals (Figure 1).

\section{Tat and HIV-I associated dementia}

Tat is also a potent chemoattractant for macrophages and monocytes and dendritic cells, but not lymphocytes $[16,61]$. Region II of Tat has positions of amino acid similarity with key residues in $\beta$-chemokines critical for chemokine receptor binding and signal transduction [61], including a CCF/Y motif at positions 30-32, a strongly conserved Ile ${ }^{39}$ and a SYXR motif at position 46-49. B Tat induces chemotaxis of monocytes, but not lymphocytes through a CCR2-dependent mechanism that is dependent upon the integrity of the ${ }^{30} \mathrm{CC}$ motif of Tat $[16,61]$. The C31S mutation found in C Tat variants abrogates its ability to act as a chemoattractant for monocytes as it fails to bind CCR2 and induces a transient flux in cytosol $\mathrm{Ca}^{2+}$ [61].

The role of Tat in the development of neurocognitive impairment remains controversial $[62,63]$, but there is evidence of Tat mediating neurotoxicity through its regions II and IV $[64,65]$. Tat has been detected in postmortem HIV-1 encephalitic central nervous system (CNS) tissue in various infected cells $[66,67]$ as well as in uninfected oligodendrocytes [68]. It is interesting to note that in India where the C subtype is prevalent, the HIV-1 associated dementia is rare [69] and this could be due to the C31S mutation [61]. Nevertheless, despite extensive in vitro research and in vivo animal studies demonstrating a potential role for Tat in HIV-related CNS impairment, no study to date has directly quantified the in vivo levels of secreted Tat in the CNS as Tat is rapidly degraded postmortem [67]. In a mouse model of brain toxicity, after a single intraventricular injection of Tat, macrophage infiltration, progressive glial activation, and neuronal apoptosis were observed over several days, while within 6 hours Tat was undetectable [70]. Tat also crosses the blood-brain barrier (BBB) and enters the CNS where it has toxic consequences [71]. It interacts with microglia, astrocytes and brain endothelial cells, increasing the expression of inducible nitric oxide synthase and release of nitric oxide [72] and TNF [14], as well as disrupting tight-junction distribution, increasing the blood brain barrier (BBB) permeability [73]. Tat also exerts a neurotoxic effect on hippocampal neurons by disinhibiting $\mathrm{Ca}^{2+}$-permeable N-methyl-D-aspartate (NMDA) receptors from $\mathrm{Zn}^{2+}$ mediated antagonism, thereby potentiating the NMDAmediated death [74]. Subtype C Tat is less neurotoxic than subtype B Tat as a result of the C31S mutation with experiments underway to explain this effect [13].

The influence of Tat on the transcription of TNF from monocytes and microglial cells is particularly important in HIV-1 pathogenesis [14] with patients suffering from
HIV-1-associated dementia (HAD) having increased expression of TNF and TNF receptors on activated macrophages and monocytes in both the white matter of brain tissue and sera [75]. TNF opens a paracellular route for HIV invasion across the BBB [76], induces the expression of adhesion molecules on astrocytes and endothelial cells [77] and induces the release of chemokine factors from monocytes and microglial cells allowing HIV-1 infected monocytes and macrophages to transmigrate into the CNS [75]. However, TNF also has neuroprotective effects, such as upregulating the production of CCL5 from astrocytes and Bcl-2 from neurons [75], illustrating the multifactorial cause of the disease. B Tat upregulates TNF production from microglial cells and monocytes through a calcium dependent mechanism that involves an increase in intracellular $\mathrm{Ca}^{2+}$ through L-type calcium channels [14]. Subtype C Tat, which fails to induce an intracellular calcium flux due to its C31S mutation, is still able to induce TNF production, although at much reduced levels [14]. The key checkpoint in TNF protein production in monocytic cells is the transcriptional activation of the gene where histone acetyltransferases and chromatin remodeling play critical roles in enhanceosome formation and are required for TNF gene activation. Both subtype B and $\mathrm{C}$ Tat aid in these functions, but the mutation of $\mathrm{F} /$ Y32W present in CRF_AE Tat interferes with chromatin remodeling of the TNF locus and with the recruitment of p300/CBP-associating factor to the TNF promoter, resulting in lower levels of TNF gene expression and protein production in T cells [19]. The effect of CRF_AE Tat on TNF production from monocytes has not yet been evaluated.

\section{Apoptosis and the role of Tat}

The hallmark of disease progression in HIV-1 infected individuals is an increased virus load [78] and the progressive loss of CD4+ $\mathrm{T}$ cells [79]. Apoptosis, autophagy and activation-induced cell death (AICD) are known to be involved in this process [80-82]. Co-culture experiments of HIV-1 infected and uninfected cells have shown that while HIV-1-infected cells are resistant to HIV-induced death, uninfected bystander CD4+ T cells undergo apoptosis [83]. Some studies have suggested that Tat induces AICD and has no effect on resting CD4 ${ }^{+} \mathrm{T}$ cells $[84,85]$, whereas others have shown that activation is unnecessary and Tat can directly induce apoptosis in resting CD4+ $\mathrm{T}$ cells $[14,15,86,87]$. However, no study has addressed the role autophagy may play in Tat-induced apoptosis, although two Tat studies used serum deprivation as a means to initiate apoptosis [14,15]. During starvation, autophagy contributes to the maintenance of cellular homeostasis by maintaining an amino acid reserve for glucogenesis and for the synthesis of essential proteins by targeting cell organelles and aggregates of long-lived proteins for degradation and recycling. However, it may also 
result in autophagy-associated cell death [88]. The proteins LC3B-II, Beclin I and ATG7 are essential for the latter. Beclin-1 possesses a $\mathrm{BH} 3$ domain that interacts with the $\mathrm{BH} 3$ receptor domain of the anti-apoptotic proteins of the Bcl-2 family. BH3-only proteins can induce autophagy by competitively disrupting the interaction of Beclin-1 with $\mathrm{Bcl}-2 / \mathrm{Bcl}-\mathrm{X}_{\mathrm{L}}$, linking the apoptosis and autophagy machinery. One such BH3-only protein, Bad, is known to be activated upon the withdrawal of growth factors [88].

Tat also induces apoptosis by binding to tubulin at the pharmacological site of paclitaxel, enhancing tubulin polymerization [18] and preventing depolymerization [89]. Tubulin polymers form microtubules necessary for cellular morphology, intracellular organelle distribution, chromosome migration during mitosis, cell differentiation, as well as intracellular transport and signaling [90]. Inhibition of microtubule dynamics induces $\mathrm{M}$ arrest, mitotic spindle assembly checkpoint activation, Bcl-2 phosphorylation, c-and Jun NH(2)-terminal kinase activation, leading to apoptosis. Furthermore, as microtubules serve as scaffolds for signaling molecules that regulate apoptosis, such as Bim, disruption of microtubule dynamics releases these signaling molecules from microtubules, which then induce mitochondrial membrane permeabilization resulting in the release of critical pro-apoptotic intermembrane space effectors into the cytosol such as cytochrome $c$, apoptosis-inducing factor, Smac/Diablo, Endo G, and pro-caspases [91]. Regions II and III of Tat including the conserved $\mathrm{Cys}^{37}$ and $\mathrm{Phe}^{38}$ are crucial to Tat-tubulin interactions [89]. This region differs from those present in the tubulin-binding domains of conventional microtubule-associated proteins, which typically contain positively charged residues [92]. It is possible that the basic region III of Tat provides the positive charge necessary to neutralize the negatively charged Ctermini of tubulin promoting microtubule assembly. The glutamine-rich region $\mathrm{V}$ may also play a role in providing the structural conformation required for the Tat-tubulin interaction [14]. In a study of two subtype D 86-residue Tat proteins, it was found that mutations in this region that disturb the formation of an $\alpha$-helix reduced the ability of Tat to bind and polymerize tubulin [14]. Further evidence for this interaction was provided in a comparison of long versus short Tat in inducing $\mathrm{CD} 4^{+} \mathrm{T}$ cell apoptosis [15]. The short form was less effective than the long form [15]. In the NMR study of the full-length 99 residue Tat Eli, the C-terminus of Tat masks the $\alpha$-helix of the glutamine-rich region [38], possibly reducing this Tat's ability to bind to tubulin.

Tat is also capable of inducing apoptosis in Bim-/- cells [89]. Another pathway by which Tat has been shown to induce the apoptosis of bystander $\mathrm{CD}^{+} \mathrm{T}$ cells is by upregulating Fas ligand (CD178) expression in both infected and uninfected bystander cells [14,15,93]. HIV-1infected individuals have CD4+ and CD8 ${ }^{+} \mathrm{T}$ cells that are more susceptible to CD178-induced apoptosis. Furthermore, CD4 ${ }^{+} \mathrm{T}$ cells from HIV-1-infected individuals overexpress Fas (CD95), and the proportion of these increases with disease progression [94]. Therefore, the upregulation of CD178 by Tat may lead to increased apoptosis in the antigen-responding $\mathrm{T}$ cells that are overexpressing CD95 [94]. In the only comparison of long versus short Tat proteins ability to induce CD4+ T cell apoptosis, it was shown that the short 86-residue form of Tat upregulates more CD178 mRNA leading to an increases in caspase- 8 that was not observed with the full length form [15], highlighting the importance of the C-terminus of Tat.

\section{Development of an HIV-I vaccine using Tat}

This review will focus on vaccine approaches using full Tat. The difficulty in reviewing all the vaccine approaches that have included Tat or parts of Tat with other HIV proteins is to determine if the effect observed is related to Tat. A good pharmaceutical practice should be to test each active principle separately before testing together to see if a synergic effect is possible. Furthermore it is important to note that stability of a vaccine in solution for at least one month is mandatory for a vaccination campaign. Adherence to these criteria would reduce significantly the number of vaccine projects actually developed against AIDS and would allow one to focus on vaccines that have a chance to be efficient in the field.

Biologically active Tat appears to be a safe approach as indicated by safety studies carried out on monkeys in which no local or systemic toxicity or adverse effects were observed [95-99]. The two main vaccine strategies against Tat up to now use a short, 86 residue version of a B-subtype European Tat variant that is either inactivated [95] or has full activity [96]. These two approaches were tested on macaques followed by a homologous SHIV-1 challenge $[96,100]$. A significant decrease of viremia was observed in these two studies carried out respectively on Cynomolgus [96] and Rhesus macaques [100], without showing complete protection during primary infection. Another study showed a long term control of infection following SHIV-1 challenge on Tat vaccinated Cynomolgus macaques [101].

\section{Conflicting results regarding Tat vaccination}

It is interesting to note that conflicting results appears in Tat vaccine studies on macaques since no protection was observed with a SIV challenge [102] or a vaccination with a recombinant virus coding for a Tat-Rev protein [103]. These conflicting results could be explained by different immunization regimens, viral stocks, routes of viral challenge, and animal species. The difference between SIV Tat and HIV-1 Tat in the first study and the probability that a 
Tat-Rev recombinant protein does not have the native Tat folding or the native Rev folding for the second study may explain the absence of protection. More puzzling, however, are the results of two other studies using similar viral vectors expressing Tat, Env and Gag that gave opposite conclusions. One study showed the efficacy of vectored Tat, but not Gag and Env [104], while another study showed efficacy of vectored Gag and Env, but not Tat [105]. The main difference in the two studies was that one used a homologous challenge with the Tat Bru sequence in both the vaccine and in the SHIV [104] while the other used a heterologous challenge with the Tat Bru sequence in the vaccine and Tat JR in the SHIV [105]. HIV-1 JR and HIV-1 Bru are B subtypes (Figure 1), but their Tat sequences have non-conservative mutations inducing conformational changes [43]. Theses mutations between the vaccine and the virus used for the challenge might explain the lack of efficacy of the Tat vectored vaccine in the second study [105]. The second study resembled more closely reality since a vaccinated person would not likely be exposed to a homologous virus infection. However, it is not clear why the investigators in the same experiment used a homologous Gag and Env [105].

Over the last 20 years, HIV-1 vaccine studies that target the HIV-1 envelope proteins have been tested using a homologous SHIV/macaque model and have met with some success [106]. However, this was not followed by success in clinical trials [107]. This is likely due to the high genetic diversity of HIV-1, and this is a reason why heterologous SHIV challenge in macaques, with a genetically distinct virus, should be used to determine if a vaccine can be effective against HIV-1 infection in humans [106]. If a successful homologous SHIV challenge is used to provide support for Tat vaccination in vivo, then the development of a worldwide Tat vaccine in humans need to additionally take into account the genetic diversity of HIV-1 Tat proteins. In this regard, it is important to note that immunization with the B subtype Tat Bru does not stimulate an efficient response against Tat variants from $\mathrm{A}$ and $\mathrm{C}$ subtypes [41].

\section{Tat antibodies in human sera}

The interest in developing a Tat vaccine rose with the discovery that seropositive long-term non-Progressor (LTNP) patients had a higher level of Tat antibodies than seropositive Rapid Progressor (RP) patients [49,50,95 ,108,110, 111]. It is notable that with a sera dilution of 1:1000, Tat Bru is recognized by only $30 \%$ of the RP patients in Europe [95] and only 10 to $14 \%$ of RP patients in Africa [111]. This percentage can reach up to $50 \%$ in Africa if other Tat variants from subtypes A, C and D are tested [17]. This result outlines again how mutations in Tat variants can affect immunogenicity, but it shows also that a large amount of seropositive patients are unable to recog- nize Tat. Furthermore Tat antibodies in African RP patients have no effect on their progression to AIDS [34]. Thus for a majority of HIV-1 infected patients, Tat is not recognized and although this protein is present in the circulating of infected individuals, those who recognize Tat can apparently not neutralize this protein.

\section{Low cross recognition between Tat variants}

Only region IV is well conserved among Tat variants (Figure 1), but this region is not recognized by sera from HIV1 infected patients [17]. Why the basic region of Tat is not recognized by the human immune system could be due to sequence similarity of the basic region of Tat ( ${ }^{48}$ GRKKRRQRRR) with epitopes found in human proteins such as protamine ( ${ }^{24}$ RSCRRRKRRSCR). It is interesting to note that two thirds of new born children from HIV-1 infected mother succeed to escape HIV-1 infection that can occur during the delivery or the breastfeeding and generally sero-revert when they are eighteen months old [112]. This high proportion excludes genetic factors that could be due to an innate immunity against HIV. It could be possible that a repression of the immune system to recognize Tat may exist in adults, but not among new born children since the full expression of protamine arrives with sexual maturation.

In the other Tat regions that appear to be recognized by the immune system, a high level of mutations exists since $40 \%$ of Tat can be mutated without loss of activity [17]. It is clear that the discrepancy in two studies on the same cohort regarding the number of patients who recognize Tat in Uganda $[17,111]$ is related to the absence of cross recognition by antibodies to African Tat variants when they used to detect an European Tat variant [111]. This finding was previously reported with vaccination of rabbits with different Tat variants [41], and it illustrated that a Tat vaccine using a European variant would be inefficient in Africa where the majority of the HIV infected individuals are located.

\section{Innate and acquired immunity}

More attention should be placed on the natural immunity against HIV. Natural immunity against HIV-1 is observed in a low proportion of the human population and encompasses different mechanisms ranging from chemokine mutations to the capacity to produce neutralizing antibodies against the HIV-1 envelope $[112,113]$. Natural immunity can be innate or acquired, the latter being of course the most interesting for vaccine development. Patients with natural immunity against HIV-1 can be exposed and still remain persistently seronegative (EPS), or they can be seropositive and remain long term non progressors (LTNP). In most cases, this natural immunity turns out to reflect innate immunity. However, there is a very rare category of EPS patients highly exposed to the 
virus who are resistant to HIV-1 due apparently to an acquired immunity. This was revealed by EPS patients in Kenya who were sex workers and who became seropositive and then developed AIDS after a lapse in sex work, showing that their former resistance to HIV-1 was not innate [114]. Kenyan sex workers who are EPS had been intensely studied, and their resistance to HIV-1 appears to be related to their capacity to develop an efficient CD8 T cell response against HIV-1 [115]. However, the paradox is that the CD8 T cell response in EPS Kenyan sex workers is five times lower in magnitude than that of seropositive Kenyan sex workers who ultimately develop AIDS [116]. To make things even more puzzling, studies of similar cohorts of EPS individuals in Ivory Cost, Vietnam and Cambodia show that they have no HIV-1 specific CD8 T cell response but do have natural killer (NK) cell responses [117,118], antibodies against HIV-1 envelop proteins [119], or cellular factors that affect steps of viral entry [120].

\section{Acquired immunity against HIV-I in a cohort in Gabon}

During the eighties in Africa, it was observed in a remote area of Gabon called "Haut Ogooué" that seropositive individuals were not developing AIDS and that they ultimately could sero-revert $[121,122]$. An epidemiological survey was designed and carried out on 750 pregnant women for two years, and 25 were identified as seropositive [122]. From these 25 seropositive women, 23 seroreverted and became EPS during the two years of the survey. Although EPS patients have normally no detectable virus, it was possible to isolate and clone a HIV-1 strain from one patient called Oyi when she was seropositive [122]. Contrary to other EPS cohort of sex workers or drug users that were constituted many years after the first exposure to HIV, the Gabon cohort was constituted during the primary infection, and this may explain why it was possible to clone a virus. All women infected with HIV-1 Oyi sero-reverted but maintained a CTL response against HIV1 and had antibodies against P24 [122]. Some women infected by HIV-1 Oyi were also infected by a highly virulent strain similar to HIV-1 Eli [122]. The high proportion of EPS phenotype in this cohort (92\%) indicated that the resistance to HIV-1 was probably due to an acquired immunity and not an innate immunity that is statistically observed in less than $5 \%$ of the population. Ten years after the publication of the above study, the 23 women remained in good health and traces of HIV-1 infection were no longer detectable in their blood (Eric Delaporte, personal communication). It is interesting to note that HIV-1 infection appears to be very low in Gabon compared to other central African countries [123].

HIV-1 Oyi has genes similar to regular HIV-1 strains except the tat gene, which has mutations never found in other Tat variants [43]. Immunization with Tat Oyi raises antibodies in rabbits that were able to recognize different Tat variants even with mis-matched amino acids of up to $38 \%$; this phenomenon has not been seen from immunization with other Tat variants [41]. Tat Oyi appears to induce a humoral immune response against a threedimensional epitope that is conserved in other Tat variants, and this humoral response could make it possible to neutralize extracellular Tat. Recently, it was shown that Tat Oyi immunization of macaques induced a predominant Th2 immune response while a predominant Th1 immune response was commonly observed after immunization with a non-Oyi Tat [124].

The role of extracellular Tat was not known during the nineteen eighties, and the presence of antibodies against Tat was not tested in this Gabon cohort [122]. However, we recently were able to detect Tat antibodies in a cohort of EPS patients in Vietnam (data not published). Two third of the patients had Tat antibodies characterized by the capacity to recognize Tat variants from the five main HIV-1 subtypes (data not published), while RP seropositive patients recognized mainly Tat variants from one or two HIV-1 subtypes [17].

\section{Heterologous SHIV challenge after vaccination with Tat Oyi}

Seven rhesus macaques were immunized with synthetic Tat Oyi complemented with an adjuvant, and then a heterologous challenge with the European SHIV BX08 was carried out on Tat Oyi vaccinated macaques and control macaques. Tat Oyi vaccinated macaques had lower viremia compared with control macaques. The most interesting finding was that SHIV infected cells were no longer detectable at 8 weeks post-challenge in Tat Oyi vaccinated macaques. Surprisingly, the macaque that had the lowest viremia had no antibodies against SHIV envelop proteins. This macaque was challenged again, and the animal experienced a short period of seropositivity and sero-reverted [47]. It was, therefore, possible to reproduce experimentally in vivo what is observed in the field with EPS patients. This experiment of heterologous SHIV challenge after Tat Oyi vaccination shows that it could be possible to dramatically reduce the level of HIV infected cells in HIV infected patients. Of note, this goal has never been achieved with antiviral treatments.

As a conclusion, a vaccine approach using Tat should take in account the mutations that can occur in Tat variants. Conformational epitopes are essential to obtain cross recognition of Tat variants and therefore a full Tat protein with the second exon to have the right folding. The second exon of Tat elicits immunity against Tat [125], and a long form of the second exon improves cross recognition of Tat variants [52]. However, up to now, only the immunization with a sequence related to the Tat Oyi variant makes possible the cross recognition of Tat variants from the 
main HIV-1 subtypes, which appears to be one of the characteristics observed with antibodies able to neutralize Tat extra cellular functions.

\section{Competing interests}

The authors declare that their Tat vaccine technology is under licensing agreement with commercial for profit firms.

\section{Authors' contributions}

GRC and EPL were equally involved in drafting and revising the manuscript. Both authors read and approved the final manuscript.

\section{Acknowledgements}

EPL is funded by the Conseil Régional Provence Alpes Côte-d'Azur, Conseil Général des Bouches-du-Rhône, Ville de Marseille and Faire Face Au SIDA. EPL thanks the Université de la Méditerranée and INSERM for their support of this work.

\section{References}

I. Hemelaar J, Gouws E, Ghys PD, Osmanov S: Global and regional distribution of HIV-I genetic subtypes and recombinants in 2004. AIDS. 2006, 20(16):WI3-W23.

2. Renjifo B, Gilbert P, Chaplin B, Msamanga G, Mwakagile D, Fawzi W, Essex M, the Tanzanian Vitamin and HIV Study Group: Preferential in-utero transmission of HIV-I subtype $C$ as compared to HIV-I subtypes A or D. AIDS 2004, 18:1629-1636.

3. Bhoopat L, Rithaporn TS, Khunamornpong S, Bhoopat T, Taylor CR, Thorner PS: Cell reservoirs in lymph nodes infected with HIVI subtype $E$ differ from subtype B: identification by combined in situ polymerase chain reaction and immunohistochemistry. Mod Pathol 2006, 19:255-263.

4. Vasan A, Renjifo B, Hertzmark E, Chaplin B, Msamanga G, Essex M, Fawzi W, Hunter D: Different rates of disease progression of HIV type I infection in Tanzania based on infecting subtype. Clin Infect Dis 2006, 42:843-852

5. Kaleebu P, Nankya IL, Yirrell DL, Shafer LA, Kyosiimire-Lugemwa J, Lule DB, Morgan D, Beddows S, Weber J, Whitworth JA: Relation between chemokine receptor use, disease stage, and HIV-I subtypes $A$ and $D:$ results from a rural Ugandan cohort. J Acquir Immune Defic Syndr 2007, 45:28-33.

6. Coetzer M, Cilliers T, Ping LH, Swanstrom R, Morris L: Genetic characteristics of the V3 region associated with CXCR4 usage in HIV-I subtype $C$ isolates. Virology 2006, 356:95-105.

7. Walker PR, Ketunuti M, Choge IA, Meyers T, Gray G, Holmes EC, Morris L: Polymorphisms in Nef associated with different clinical outcomes in HIV type I subtype C-infected children. AIDS Res Hum Retroviruses 2007, 23:204-2I5.

8. Pacyniak E, Gomez ML, Gomez LM, Mulcahy ER, Jackson M, Hout DR, Wisdom BJ, Stephens EB: Identification of a region within the cytoplasmic domain of the subtype $B$ Vpu protein of human immunodeficiency virus type I (HIV-I) that is responsible for retention in the golgi complex and its absence in the Vpu protein from a subtype C HIV-I. AIDS Res Hum Retroviruses 2005, 21:379-394.

9. Bell CM, Connell BJ, Capovilla A, Venter WD, Stevens WS, Papathanasopoulos MA: Molecular characterization of the HIV type I subtype $\mathbf{C}$ accessory genes vif, vpr, and vpu. AIDS Res Hum Retroviruses 2007, 23:322-330.

10. Péloponèse JM, Collette Y, Grégoire C, Opi S, Bailly C, Campèse D, Meurs E, Olive D, Loret EP: Full peptide synthesis purification and characterization of six Tat variants. J Biol Chem 1999, 274: I|473-I| 478 .

II. Ranga U, Shankarappa R, Siddappa NB, Ramakrishna L, Nagendran R, Mahalingam M, Mahadevan A, Jayasuryan N, Satishchandra P, Shankar SK, Prasad VR: Tat protein of human immunodeficiency virus type I subtype C strains is a defective chemokine. J Virol 2004, 78:2586-2590
12. Roof P, Ricci M, Genin P, Montano MA, Essex M, Wainberg MA, Gatignol A, Hiscott J: Differential regulation of HIV-I clade-specific $B, C$, and $E$ long terminal repeats by NF-kappaB and the Tat transactivator. Virology 2002, 296:77-83.

13. Mishra M, Vetrivel S, Siddappa NB, Ranga U, Seth P: Clade-specific differences in neurotoxicity of human immunodeficiency virus-I B and C Tat of human neurons: significance of dicysteine C30C3I motif. Ann Neurol 2008, 63:366-376.

14. Campbell GR, Pasquier E, Watkins J, Bourgarel-Rey V, Peyrot V, Esquieu D, Barbier P, de Mareuil J, Braguer D, Kaleebu P, Yirrell DY, Loret EP: The Glutamine-Rich Region of HIV-I Tat Protein Involved in T cell Apoptosis. J Biol Chem 2004, 279:48I97-48204.

15. Campbell GR, Watkins JD, Esquieu D, Pasquier E, Loret EP, Spector SA: The C-terminus of HIV-I Tat modulates the extent of CDI78 mediated apoptosis of T cells. J Biol Chem 2005, 280:38376-38382.

16. Campbell GR, Watkins JD, Singh KK, Loret EP, Spector SA: Human immunodeficiency virus type I subtype $C$ Tat fails to induce intracellular calcium flux and induces reduced tumor necrosis factor production from monocytes. J Virol 2007, 8I:5919-5928.

17. Campbell GR, Senkaali D, Watkins J, Esquieu D, Opi S, Yirrell DL, Kaleebu P, Loret EP: Tat mutations in an African cohort that do not prevent transactivation but change its immunogenic properties. Vaccine 2007, 25:844I-84I7.

18. de Mareuil J, Carre M, Barbier P, Lancelot S, Opi S, Esquieu D, Watkins J, Campbell G, Prevot C, Braguer D, Peyrot V, Loret EP: HIV-I Tat protein enhances Microtubule polymerization. Retrovirology 2005, 2:5.

19. Ranjbar S, Rajsbaum R, Goldfeld AE: Transactivator of transcription from HIV type I subtype $E$ selectively inhibits TNF gene expression via interference with chromatin remodeling of the TNF locus. J Immunol 2006, I 76:4 I82-4190.

20. Jeang KT, Xiao H, Rich EA: Multifaceted activities of the HIV-I transactivator of transcription Tat. J Biol Chem 1999, 274:28837-28840.

21. Wong-Staal F, Gallo RC, Chang NT, Ghrayeb J, Papas TS, Lautenberger JA, Pearson ML, Petteway SR Jr, Ivanoff L, Baumeister K, Whitehorn EA, Rafalski JA, Doran JR, Josephs SJ, Starcich B, Livak KJ, Patarca R, Haseltine WA, Ratner L: Complete nucleotide sequence of the AIDS virus HTLV-III. Nature 1985, 3 1 3:277-284.

22. Fujisawa J, Seiki M, Kiyokawa T, Yoshida M: Functional activation of the Long Terminal Repeat of Human T cell leukemia virus type I by a trans-acting factor. Proc Natl Acad Sci USA 1985, 82:2277-228I.

23. Cullen BR: The HIV-I Tat protein: an RNA sequence-specific processivity factor? Cell 1990, 63:655-657.

24. Bres V, Tagami H, Peloponese JM, Loret E, Jeang KT, Nakatani Y, Emiliani S, Benkirane M, Kiernan RE: Differential acetylation of Tat coordinates its interaction with the co-activators cyclin $\mathrm{TI}$ and PCAF. EMBO J 2002, 21:68II-6819.

25. Van Duyne R, Easley R, Wu W, Berro R, Pedati C, Klase Z, Kehn-Hall K, Flynn EK, Symer DE, Kashanchi F: Lysine methylation of HIVI Tat regulates transcriptional activity of the viral LTR. Retrovirology 2008, 5:40-51.

26. Vardabasso C, Manganaro L, Lusic M, Marcello A, Giacca M: The histone chaperone protein Nucleosome Assembly Protein-I (hNAP-I) binds HIV-I Tat and promotes viral transcription. Retrovirology 2008, 5:8-20.

27. Ensoli B, Barillari G, Salahuddin SZ, Gallo RC, Wong-Staal F: Tat protein of HIV-I stimulates growth of cells derived from Kaposi's sarcoma lesions of AIDS patients. Nature 1990, 345:84-86.

28. Xiao H, Neuveut C, Tiffany HL, Benkirane M, Rich EA, Murphy PM, Jeang KT: Selective CXCR4 antagonism by Tat: implications for in vivo expansion of coreceptor use by HIV-I. Proc Nat Acad Sci USA 2000, 97: I |466-I I 47 I.

29. Wadia JS, Stan RV, Dowdy SF: Transducible TAT-HA fusogenic peptide enhances escape of TAT-fusion proteins after lipid raft macropinocytosis. Nat Med 2004, 10:310-3I5.

30. Vendeville A, Rayne F, Bonhoure A, Bettache N, Montcourrier P, Beaumelle B: HIV-I Tat enters T cells using coated pits before translocating from acidified endosomes and eliciting biological responses. Mol Biol Cell 2004, I 5:2347-2360. 
31. Fittipaldi A, Ferrari A, Zoppé M, Arcangeli C, Pellegrini V, Beltram F, Giacca M: Cell membrane lipid rafts mediate caveolar endocytosis of HIV-I Tat fusion proteins. J Biol Chem 2003, 278:34|4|-34|49.

32. Gallo RC: Tat as one key to HIV-induced immune pathogenesis and Tat toxoid as an important component of a vaccine. Proc Natl Acad Sci USA 1999, 96:8324-8326.

33. Goldstein G: HIV-I Tat protein as a potential AIDS vaccine. Nat Med. 1996, 2(9):960-964.

34. Senkaali D, Kebba A, Shafer LA, Campbell G, Loret E, Paal L Van der Grosskurth $H$, Yirrell D, Kaleebu P: Tat specific binding IgG and disease progression in HIV-I infected Ugandans. AIDS Res Hum Retroviruses 2008, 24(4):587-594.

35. Kuppuswamy M, Subramania T, Srinivasan A, Chinnadurai G: Multiple functional domains of Tat the trans-activator of HIV-I defined by mutational analysis. Nucl Acid Res 1989, I 7:355I-356|.

36. Péloponèse JM, Grégoire $C$, Opi S, Esquieu D, Sturgis J, Lebrun E, Meurs E, Collette Y, Olive D, Aubertin AM, Witvrow M, Pannecouque C, De Clercq E, Bailly C, Lebreton J, Loret EP: ${ }^{1} \mathbf{H}-{ }^{13} \mathbf{C}$ nuclear magnetic resonance assignment and structural characterization of HIV-I Tat protein. CR Acad Sci III 2000, 323:883-894.

37. Grégoire C, Péloponèse JM, Esquieu D, Opi S, Campbell G, Solomiac M, Lebrun E, Lebreton J, Loret EP: Homonuclear 'H-NMR assignment and structural characterization of human immunodeficiency virus type I Tat Mal protein. Biopolymers 200I, 62:324-335.

38. Watkins J, Campbell GR, Halimi H, Loret EP: Homonuclear 'H NMR and Circular Dichroism Study of the HIV-I Tat Eli variant. Retrovirology 2008, 5:83.

39. Loret EP, Georgel P, Johnson WC, Ho PS: Circular dichroism and molecular modeling yield a structure for the complex of human immunodeficiency virus type I trans-activation response RNA and the binding region of Tat the trans-acting transcriptional activator. Proc Natl Acad Sci USA 1992 89:9734-9738.

40. Egelé C, Barbier P, Didier P, Piémont E, Allegro D, Chaloin O, Muller $S$, Peyrot $V$, Mély $Y$ : Modulation of microtubule assembly by the HIV-I Tat protein is strongly dependent on zinc binding to Tat. Retrovirology 2008, 5:62-69.

4I. Opi S, Peloponese JM Jr, Esquieu D, Campbell G, de Mareuil J, Walburger A, Solomiac M, Gregoire C, Bouveret E, Yirrell DL, Loret EP: Tat HIV-I primary and tertiary structures critical to immune response against non-homologous variants. I Biol Chem 2002, 277:35915-35919.

42. Kuiken C, Leitner T, Foley B, Hahn B, Marx P, McCutchan F, Wolinsky $S$, Korber B, (Eds): HIV Sequence Compendium. Theoretical Biology and Biophysics Group, Los Alamos National Laboratory, NM, LA-UR 0606802008.

43. Gregoire C, Loret EP: Conformational Heterogeneity in Two Regions of TAT Results in Structural Variations of this Protein as a Function of HIV-I Isolates. J Biol Chem 1996, 27I:2264I-22646

44. Bayer P, Kraft M, Ejchart A, Westendorp M, Frank R, Rosch P: Structural studies of HIV-I Tat protein. J Mol Biol 1995, 247:529-535.

45. Koken SE, Greijer AE, Verhoef K, van Wamel J, Bukrinskaya AG, Berkhout B: Intracellular analysis of in vitro modified HIV Tat protein. J Biol Chem 1994, 269:8366-7375.

46. Shojania S, O'Neil JD: HIV-I Tat is a natively unfolded protein the solution conformation and dynamics of reduced HIV-I Tat-(I-72) by NMR spectroscopy. I Biol Chem 2006, 28 I:8347-8356

47. Watkins J, Esquieu D, Campbell GR, Lancelot S, de Mareuil J, Opi S, Annappa S, Salles JP, Loret EP: Reservoir Cells no longer Detectable after a Heterologous SHIV Challenge with the Synthetic HIV-I Tat Oyi Vaccine. Retrovirology 2006, 3:8.

48. Buttò $S$, Fiorelli V, Tripiciano A, Ruiz-Alvarez MJ, Scoglio A, Ensoli F, Ciccozzi M, Collacchi B, Sabbatucci M, Cafaro A, Guzman CA, Borsetti A, Caputo A, Vardas E, Colvin M, Lukwiya M, Rezza G, Ensoli B, the Tat Multicentric Study Group: Sequence conservation and antibody cross-recognition of clade B human immunodeficiency virus (HIV) type I Tat protein in HIV-I-infected Italians Ugandans and South Africans. I Infect Dis 2003, 188: 1171 -II80.

49. Re MC, Furlini G, Vignoli M, Ramazzotti E, Roderigo G, De Rosa V, Zauli G, Lolli S, Capitani S, La Placa M: Effect of antibody to HIV-
I Tat protein on viral replication in vitro and progression of HIV-I disease in vivo. J Acquir Immune Defic Syndr Hum Retrovirol 1995, 10:408-416.

50. Re MC, Vignoli M, Furlini G, Gibellini D, Colangeli V, Vitone F, La Placa M: Antibodies against full-length Tat protein and some low-molecular-weight Tat-peptides correlate with low or undetectable viral load in HIV-I seropositive patients. J Clin Virol 200I, 21:8I-89.

5I. Fanales-Belasio E, Moretti S, Nappi F, Barillari G, Micheletti F, Cafaro A, Ensoli B: Native HIV-I Tat protein targets monocytederived dendritic cells and enhances their maturation, function, and antigen-specific $\mathbf{T}$ cell responses. J Immunol 2002, 168:197-206.

52. Opi S, Peloponese JM Jr, Esquieu D, Watkins J, Campbell G, de Mareuil J, Jeang KT, Yirrell DL, Kaleebu P, Loret EP: Full-length HIV-I Tat protein necessary for a vaccine. Vaccine 2004, 22:3|05-3||I.

53. Ensoli B, Buonaguro L, Barillari G, Fiorelli V, Gendelman R, Morgan RA, Wingfield P, Gallo RC: Release uptake and effects of extracellular human immunodeficiency virus type I Tat protein on cell growth and viral transactivation. I Virol 1993 67:277-287.

54. Ensoli B, Gendelman R, Markham P, Fiorelli V Colombini S, Raffeld M, Cafaro A, Chang HK, Brady JN, Gallo RC: Synergy between basic fibroblast growth factor and HIV-I Tat protein in induction of Kaposi's sarcoma. Nature 1994, 37 I:674-680.

55. Huang SK, Martin FJ, Jay G, Vogel J, Papahadjopoulos D, Friend DS: Extravasation and transcytosis of liposomes in Kaposi's sarcoma-like dermal lesions of transgenic mice bearing the HIV tat gene. Am J Pathol 1993, 143:10-14.

56. Barillari G, Sgadari C, Palladino C, Gendelman R, Caputo A, Morris CB, Nair BC, Markham P, Nel A, Sturzl M, Ensoli B: Inflammatory cytokines synergize with the HIV-I Tat protein to promote angiogenesis and Kaposi's sarcoma via induction of basic fibroblast growth factor and the alpha(v)beta(3) integrin. $J$ Immunol 1999, 163:1929-1935.

57. Barillari G, Sgadari C, Fiorelli V, Samaniego F, Colombini S, Manzari V, Modesti A, Nair BC, Cafaro A, Sturzl M, Ensoli B: The Tat protein of human immunodeficiency virus type-I promotes vascular cell growth and locomotion by engaging the alpha 5 beta I and alpha $\mathrm{v}$ beta 3 integrins and by mobilizing sequestered basic fibroblast growth factor. Blood 1999, 94:663-672.

58. Barillari G, Gendelman R, Gallo RC, Ensoli B: The Tat protein of human immunodeficiency virus type I a growth factor for AIDS Kaposi sarcoma and cytokine-activated vascular cells induces adhesion of the same cell types by using integrin receptors recognizing the RGD amino acid sequence. Proc Natl Acad Sci USA 1993, 90:794I-7945.

59. Benelli R, Barbero A, Ferrini S, Scapini P, Cassatella M, Bussolino F, Tacchetti C, Noonan DM, Albini A: : Human immunodeficiency virus transactivator protein (Tat) stimulates chemotaxis, calcium mobilization, and activation of human polymorphonuclear leukocytes: implications for Tat-mediated pathogenesis. J Infect Dis 2000, 182:1643-165I.

60. Vogel BE, Lee SJ, Hildebrand A, Craig W, Pierschbacher MD, WongStaal F, Ruoslahti E: A novel integrin specificity exemplified by binding of the alpha(v)beta(5) integrin to the basic domain of the HIV Tat protein and vitronectin. J Cell Biol 1993, | 2 I:46| -468 .

61. Albini A, Ferrini S, Benelli R, Sforzini S, Giunciuglio D, Aluigi MG, Proudfoot AE, Alouani S, Wells TN, Mariani G, Rabin RL, Farber JM, Noonan DM: HIV-I Tat protein mimicry of chemokines. Proc Natl Acad Sci USA 1998, 95:13153-13158.

62. Minghetti L, Visentin S, Patrzio M, Franchini L, Ajmone-Cat MA, Levi G: Multiple actions of the human immunodeficiency virus type-I Tat protein on microglial cell functions. Neurochem Res 2004, 29:965-978.

63. King JE, Eugenin EA, Buckner CM, Berman JW: HIV tat and neurotoxicity. Microbes Infect 2006, 8: I 347-1357.

64. Gourdou I, Mabrouk K, Harkiss G, Marchot P, Watt N, Hery F, Vigne $R$ : Neurotoxicity in mice due to cysteine-rich parts of visna virus and HIV-I Tat proteins. C R Acad Sci III 1990, 3 II(4): I49-I55.

65. Sabatier JM, Vives E, Mabrouk K, Benjouad A, Rochat H, Duval A, Hue $B$, Bahraoui E: Evidence for neurotoxic activity of tat from 
human immunodeficiency virus type I. J Virol |99I, 65(2):961-967.

66. Hofman FM, Dohadwale MM, Wright AD, Hinton DR, Walker SM: Exogenous tat protein activates central nervous systemderived endothelial cells. J Neuroimmunol 1994, 54:19-28.

67. Hudson L, Liu J, Nath A, Jones M, Raghavan R, Narayan O, Male D, Everall I: Detection of the human immunodeficiency virus regulatory protein tat in CNS tissues. J Neurovirol 2000, 6: I 45- I 55.

68. Nath A, Geiger JD, Mattson MP, Magnuson DSK, Jones M, Berger JR Role of viral proteins in HIV-I neuropathogenesis with emphasis on Tat. NeuroAIDS 1998, I:6-II.

69. Siddappa NB, Venkatramanan M, Venkatesh $P$, Janki MV, Jayasuryan N, Desai $A$, Ravi $V$, Ranga $U$ : Transactivation and signaling functions of Tat are not correlated: biological and immunological characterization of HIV-I subtype-C Tat protein. Retrovirology 2006, 3:53.

70. Jones M, Olafson K, Del Bigio MR, Peeling J, Nath A: Intraventricular injection of human immunodeficiency virus type I (HIVI) tat protein causes inflammation gliosis apoptosis and ventricular enlargement. J Neuropathol Exp Neurol 1998, 57:563-570.

71. Banks WA, Robinson SM, Nath A: Permeability of the bloodbrain barrier to HIV-I Tat. Exp Neurol 2005, 193:2 18-227.

72. Kim TA, Avraham HK, Koh YH, Jiang S, Park IW, Avraham S: HIV-I Tat-mediated apoptosis in human brain microvascular endothelial cells. J Immunol 2003, 1 70:2629-2637.

73. Weiss JM, Nath A, Major EO, Berman JW: HIV-I Tat induces monocyte chemoattractant protein-I-mediated monocyte transmigration across a model of the human blood-brain barrier and up-regulates CCR5 expression on human monocytes. J Immunol I999, 163:2953-2959.

74. Chandra T, Maier W, König HG, Hirzel K, Kögel D, Schüler T, Chandra A, Demirhan I, Laube B: Molecular interactions of the type I human immunodeficiency virus transregulatory protein Tat with $\mathbf{N}$-methyl-d-aspartate receptor subunits. Neuroscience 2005, 34: I 45- 153

75. Brabers NA, Nottet HS: Role of the pro-inflammatory cytokines TNF-alpha and IL-I beta in HIV-associated dementia. Eur J Clin Invest 2006, 36:447-458.

76. Fiala MDJ, Looney M, Stins DD, Way L, Zhang X, Gan F, Chiappelli ES, Schweitzer P, Shapshak M, Weinand MC, Graves M, Witte K, Kim S: TNF-alpha opens a paracellular route for HIV-I invasion across the blood-brain barrier. Mol Med 1997, 3:553-564.

77. Brack-Werner R: Astrocytes: HIV cellular reservoirs and important participants in neuropathogenesis. AIDS 1999, 13:1-22.

78. Furtado MR, Kingsley LA, Wolinsky SM: Changes in the viral mRNA expression pattern correlate with a rapid rate of CD4+ T-cell number decline in human immunodeficiency virus type I-infected individuals. J Virol 1995, 4:2092-2100.

79. Gougeon ML, Lecoeur H, Dulioust A, Enouf MG, Crouvoiser M, Goujard C, Debord T, Montagnier L: Programmed cell death in peripheral lymphocytes from HIV-I-infected persons: increased susceptibility to apoptosis of CD4 and CD8 T cells correlates with lymphocyte activation and with disease progression. J Immunol 1996, I 56:3509-3520.

80. Ameisen JC, Capron A: Cell dysfunction and depletion in AIDS: the programmed cell death hypothesis. Immunol Today I99I, 1 2:102-105.

8I. Noraz N, Gozlan J, Corbeil J, Brunner T, Spector SA: HIV-induced apoptosis of activated primary CD4+ T lymphocytes is not mediated by Fas-Fas ligand. AIDS 1997, I I:167I-1680.

82. Espert L, Denizot M, Grimaldi M, Robert-Hebmann V, Gay B, Varbanov $M$, Codogno $P$, Biard-Piechaczyk $M$ : Autophagy is involved in $T$ cell death after binding of HIV-I envelope proteins to CXCR4. J Clin Invest 2006, 8:2161-2172.

83. Nardelli B, Gonzalez C], Schechter M, Valentine FT: CD4+ blood lymphocytes are rapidly killed in vitro by contact with autologous human immunodeficiency virus-infected cells. Proc Natl Acad Sci USA 1995, 92:7312-7316.

84. Bartz SR, Emerman M: Human immunodeficiency virus type I Tat induces apoptosis and increases sensitivity to apoptotic signals by up-regulating FLICE/caspase-8. J Virol 1999, 73:1956-1963

85. Gülow K, Kamiński M, Darvas K, Süss D, Li-Weber M, Krammer PH: HIV-I trans-activator of transcription substitutes for oxida- tive signaling in activation-induced $\mathbf{T}$ cell death. J Immunol 2005, 174:5249-5260.

86. Li CJ, Friedman DJ, Wang C, Metelev V, Pardee AB: Induction of apoptosis in uninfected lymphocytes by HIV-I Tat protein. Science 1995, 268:429-431.

87. Patki AH, Lederman MM: HIV-I Tat protein and its inhibitor Ro 24-7429 inhibit lymphocyte proliferation and induce apoptosis in peripheral blood mononuclear cells from healthy donors. Cell Immunol 1996, 169:40-46.

88. Yu L, Alva A, Su H, Dutt P, Freundt E, Welsh S, Baehrecke EH, Lenardo MJ: Regulation of an ATG7-beclin I program of autophagic cell death by caspase-8. Science 2004, 304: $1500-1502$

89. Chen D, Wang M, Zhou S, Zhou Q: HIV-I Tat targets microtubules to induce apoptosis a process promoted by the proapoptotic Bcl-2 relative Bim. EMBO J 2002, 2I:680I-68I0.

90. Jordan MA, Wilson L: Microtubules as a target for anticancer drugs. Nat Rev Cancer 2004, 4:253-265.

91. Pourroy B, Carre M, Honore S, Bourgarel-Rey V, Kruczynski A, Briand $C$, Braguer D: Low Concentrations of Vinflunine Induce Apoptosis in Human SK-N-SH Neuroblastoma Cells through a Postmitotic GI Arrest and a Mitochondrial Pathway. Mol Pharmacol. 2004, 66(3):580-591.

92. Hirokawa N: Microtubule organization and dynamics dependent on microtubule-associated proteins. Curr Opin Cell Biol 1994, 4:74-8I.

93. Cohen SS, Li C, Ding L, Cao Y, Pardee AB, Shevach EM, Cohen DI: Pronounced acute immunosuppression in vivo mediated by HIV Tat challenge. Proc Natl Acad Sci USA 1999, 96: I0842- 10847.

94. Aries SP, Schaaf B, Muller C, Dennin RH, Dalhoff K: CD95 (CD95) expression on CD4+ $T$ cells from HIV-I-infected patients increases with disease progression. J Mol Med 1995, 73:59I-593.

95. Zagury JF, Sill A, Blattner W, Lachgar A, Le Buanec H, Richardson M, Rappaport J, Hendel H, Bizzini B, Gringeri A, Carcagno M, Criscuolo M, Burny A, Gallo RC, Zagury D: Antibodies to the HIV-I Tat protein correlated with nonprogression to AIDS a rationale for the use of Tat toxoid as an HIV-I vaccine. J Hum Virol I998, I:282-292.

96. Cafaro A, Caputo A, Fracasso C, Maggiorella MT, Goletti D, Baroncelli S, Pace M, Sernicola L, Koanga-Mogtomo ML, Betti M, Borsetti A, Belli R, Akerblom L, Corrias F, Butto S, Heeney J, Verani P, Titti F, Ensoli B: Control of SHIV-89.6P-infection of cynomolgus monkeys by HIV-I Tat protein vaccine. Nat Med 1999, 6:643-650.

97. Cafaro A, Titti F, Fracasso C, Maggiorella MT, Baroncelli S, Caputo A, Goletti D, Borsetti A, Pace M, Fanales-Belasio E, Ridolfi B, Negri DR, Sernicola L, Belli R, Corrias F, Macchia I, Leone P, Michelini Z, Ten Haaft P, Butto S, Verani P, Ensoli B: Vaccination with DNA containing tat coding sequences and unmethylated $C$ pG motifs protects cynomolgus monkeys upon infection with simian/ human immunodeficiency virus (SHIV89.6P). Vaccine 200I, 19:2862-2877.

98. Caselli E, Betti M, Grossi MP, Balboni PG, Rossi C, Boarini C, Cafaro A, Barbanti-Brodano G, Ensoli B, Caputo A: DNA immunization with HIV-I tat mutated in the trans activation domain induces humoral and cellular immune responses against wild-type Tat. J Immunol 1999, 162:563 I-5638.

99. Goldstein G, Manson K, Tribbick G, Smith R: Minimization of chronic plasma viremia in rhesus macaques immunized with synthetic HIV-I Tat peptides and infected with a chimeric simian/human immunodeficiency virus (SHIV33). Vaccine 2000, 25:2789-2795.

100. Pauza CD, Trivedi P, Wallace M, Ruckwardt TJ, Le Buanec H, Lu W, Bizzini B, Burny A, Zagury D, Gallo RC: Vaccination with tat toxoid attenuates disease in simian/HIV-challenged macaques. Proc Natl Acad Sci USA 2000, 97:3515-3519.

10I. Maggiorella MT, Baroncelli S, Michelini Z, Fanales-Belasio E, Moretti $S$, Sernicola L, Cara A, Negri DR, Butto S, Fiorelli V, Tripiciano A, Scoglio A, Caputo A, Borsetti A, Ridolfi B, Bona R, ten Haaft P, Macchia I, Leone P, Pavone-Cossut MR, Nappi F, Ciccozzi M, Heeney J, Titti F, Cafaro A, Ensoli B: Long-term protection against SHIV89.6P replication in HIV-I Tat vaccinated cynomolgus monkeys. Vaccine 2004, 22:3258-3269.

102. Allen TM, Mortara L, Mothe BR, Liebl M, Jing P, Calore B, Piekarczyk M, Ruddersdorf R, O'Connor DH, Wang X, Wang C, Allison DB, Altman JD, Sette A, Desrosiers RC, Sutter G, Watkins DI: Tat-vacci- 
nated macaques do not control simian immunodeficiency virus SIVmac239 replication. J Virol 2002, 76:4I08-4II 2.

103. Verrier B, Le Grand R, Ataman-Onal Y, Terrat C, Guillon C, Durand PY, Hurtrel B, Aubertin AM, Sutter G, Erfle V, Girard M: Evaluation in rhesus macaques of Tat and Rev-targeted immunization as a preventive vaccine against mucosal challenge with SHIV-BX08. DNA Cell Biol 2002, 21:653-658.

104. Stittelaar KJ, Gruters RA, Schutten M, van Baalen CA, van Amerongen G, Cranage M, Liljestrom P, Sutter G, Osterhaus AD: Comparison of the efficacy of early versus late viral proteins in vaccination against SIV. Vaccine 2002, 20:292I-2927.

105. Liang X, Casimiro DR, Schleif WA, Wang F, Davies ME, Zhang ZQ, Fu TM, Finnefrock AC, Handt L, Citron MP, Heidecker G, Tang A, Chen M, Wilson KA, Gabryelski L, McElhaugh M, Carella A, Moyer C, Huang L, Vitelli S, Patel D, Lin J, Emini EA, Shiver JW: Gag and Env but not Tat show efficacy against simian-human immunodeficiency virus 89.6P challenge in Mamu-A*0 I-negative rhesus monkeys. / Virol 2005, 19:|232|-|233|.

106. Feinberg MB, Moore JP: AIDS vaccine models: challenging challenge viruses. Nat Med 2002, 8:207-2I0.

107. Vanichseni S, Tappero JW, Pitisuttithum P, Kitayaporn D, Mastro TD, Vimutisunthorn E, van Griensvan F, Heyward WL, Francis DP, Choopanya K, Bangkok Vaccine Evaluation Group: Recruitment, screening and characteristics of injection drug users participating in the AIDSVAX B/E HIV vaccine trial, Bangkok, Thailand. AIDS 2004, | 8:3||-3|6.

108. Van Baalen CA, Pontesilli O, Huisman RC, Geretti AM, Klein MR, de Wolf F, Miedema F, Gruters RA, Osterhaus AD: Human immunodeficiency virus type I Rev- and Tat-specific cytotoxic T lymphocyte frequencies inversely correlate with rapid progression to AIDS. J Gen Virol 1997, 78:1913-1918.

109. Addo MM, Altfeld M, Rosenberg ES, Eldridge RL, Philips MN, Habeeb K, Khatri A, Brander C, Robbins GK, Mazzara GP, Goulder PJ, Walker BD, HIV Controller Study group: The HIV-I regulatory proteins Tat and Rev are frequently targeted by cytotoxic $T$ lymphocytes derived from HIV-I-infected individuals. Proc Natl Acad Sci USA 200I, 98: 178I-1786.

1 10. Belliard G, Romieu A, Zagury JF, Dali H, Chaloin O, Le Grand R, Loret E, Briand JP, Roques B, Desgranges C, Muller S: Specificity and effect on apoptosis of Tat antibodies from vaccinated and SHIV-I-infected rhesus macaques and HIV-I-infected individuals. Vaccine 2003, 21:3186-3199.

III. Buttò S, Fiorelli V, Tripiciano A, Ruiz-Alvarez MJ, Scoglio A, Ensoli F, Ciccozzi M, Collacchi B, Sabbatucci M, Cafaro A, Guzman CA, Borsetti A, Caputo A, Vardas E, Colvin M, Lukwiya M, Rezza G, Ensoli B, Tat Multicentric Study Group: Sequence conservation and antibody cross-recognition of clade $B$ human immunodeficiency virus (HIV) type I Tat protein in HIV-I-infected Italians, Ugandans, and South Africans. J Infect Dis 2003, 188: I I7I-I I80.

I 12. Singh KK, Spector SA: Host Genetic Determinants of HIV Infection and Disease Progression in Children. Pediatr Res 2009 in press.

113. Marmor M, Hertzmark K, Thomas SM, Halkitis PN, Vogler M: Resistance to HIV infection. JUrban Health 2006, 83:5-17.

1 14. Kaul R, Rowland-Jones SL, Kimani J, Dong T, Yang HB, Kiama P, Rostron T, Njagi E, Bwayo J], MacDonald KS, McMichael AJ, Plummer FA: Late seroconversion in HIV-resistant Nairobi prostitutes despite pre-existing HIV-specific CD8+ responses. J Clin Invest 2001, 107:341-349.

115. McMichael AJ, Rowland-Jones SL: Cellular immune responses to HIV. Nature 200I, 41 0:980-987.

I 16. Alimonti JB, Kimani J, Matu L, Wachihi C, Kaul R, Plummer FA, Fowke KR: Characterization of CD8 $T$ cell responses in HIV-Iexposed seronegative commercial sex workers from Nairobi, Kenya. Immunol Cell Biol 2006, 84:482-485.

1 17. Scott-Algara D, Truong LX, Versmisse P, David A, Luong TT, Nguyen NV, Theodorou I, Barre-Sinoussi F, Pancino G: Cutting edge: increased NK cell activity in HIV-I-exposed but uninfected Vietnamese intravascular drug users. J Immunol 2003, |7|:5663-5667.

118. Jennes W, Verheyden S, Demanet C, Adje-Toure CA, Vuylsteke B, Nkengasong JN, Kestens L: Cutting Edge: Resistance to HIV-I Infection among African Female Sex Workers Is Associated with Inhibitory KIR in the Absence of Their HLA Ligands. J Immunol 2006, 177:6588-6592.
119. Nguyen M, Pean P, Lopalco L, Nouhin J, Phoung V, Ly N, Vermisse P, Henin Y, Barre-Sinoussi F, Burastero SE, Reynes JM, Carcelain G, Pancino G: HIV-specific antibodies but not $T$ cell responses are associated with protection in seronegative partners of HIV. I-infected individuals in Cambodia. J Acquir Immune Defic Syndr 2006, 42:412-4I9.

120. Saez-Cirion A, Versmisse P, Truong LX, Chakrabarti LA, Carpentier W, Barre-Sinoussi F, Scott-Algara D, Pancino G: Persistent resistance to HIV-I infection in CD4 T cells from exposed uninfected Vietnamese individuals is mediated by entry and postentry blocks. Retrovirology 2006, 3:8I-86.

121. Delaporte E, Dupont A, Merlin M, Josse R, Hamono B, Larouze B, Brun-Vezinet F: Seroepidemiological survey of HIV-I and HIV2 antibodies in Gabon. AIDS 1988, 2:136-137.

122. Huet T, Dazza MC, Brun-Vezinet F, Roelants GE, Wain-Hobson S: A highly defective HIV-I strain isolated from a healthy Gabonese individual presenting an atypical western blot. AIDS 1989, 3:707-7I5.

123. Delaporte E, Janssens W, Peeters M, Buve A, Dibanga G, Perret JL, Ditsambou V, Mba JR, Courbot MC, Georges A, Bourgeois A, Samb B, Henzel D, Heyndrickx L, Fransen K, Van der Groen G, Larouze B: Epidemiological and molecular characteristics of HIV infection in Gabon, 1986-1994. AIDS. 1996, I0(8):903-910.

124. Fanales-Belasio E, Moretti S, Fiorelli V, Tripiciano A, Pavone Cossut MR, Scoglio A, Collacchi B, Nappi F, Macchia I, Bellino S, Francavilla V, Caputo A, Barillari G, Magnani M, Laguardia ME, Cafaro A, Titti F, Monini P, Ensoli F, Ensoli B: HIV-I Tat addresses dendritic cells to induce a predominant Thl-type adaptive immune response that appears prevalent in the asymptomatic stage of infection. J Immunol. 2009, 182(5):2888-2897.

125. Smith SM, Pentlicky S, Klase Z, Singh M, Neuveut C, Lu CY, Reitz MS $\mathrm{Jr}$, Yarchoan R, Marx PA, Jeang KT: An in vivo replication-important function in the second coding exon of Tat is constrained against mutation despite cytotoxic $\mathrm{T}$ lymphocyte selection. J Biol Chem 2003, 278:448| 6-25.
Publish with BioMed Central and every scientist can read your work free of charge

"BioMed Central will be the most significant development for disseminating the results of biomedical research in our lifetime."

Sir Paul Nurse, Cancer Research UK

Your research papers will be:

- available free of charge to the entire biomedical community

- peer reviewed and published immediately upon acceptance

- cited in PubMed and archived on PubMed Central

- yours - you keep the copyright
BioMedcentral 